\title{
Does Financial Literation Moderate The Effect of Funding on The Sustainability of Micro Enterprises
}

\author{
DODY HAPSORO* \\ ADRIAN SEPTIA ISWARA \\ STIE YKPN Yogyakarta
}

\begin{abstract}
Financing is one of the main supporting factors in the sustainability of microbusinesses. Micro businesses are expected to be able to manage company finances professionally for the benefit and sustainability of their business. The purpose of this study is to examine financial literacy skills in moderating the effect of financing on the sustainability of micro-businesses. The variables tested were financing, financial literacy, and business sustainability. The population in this study is a micro-business that runs its business activities in Blora Regency, Central Java. The number of samples used in this study was 120 micro-businesses, which were determined based on the purposive sampling method. The analytical tool used to test the hypothesis is simple regression and multiple regression using SPSS version 25.0. The results showed that financing has a positive effect on the sustainability of micro-businesses, and financial literacy strengthens the effect of financing on the sustainability of micro-businesses. This study implies that micro-entrepreneurs are expected to be able to improve financial literacy skills, especially in terms of fund management, because funds obtained from financing activities are vulnerable to the possibility of fraud and mismanagement.
\end{abstract}

Keywords: Financing, financial literacy, business sustainability, micro-enterprises

\begin{abstract}
Abstrak: Pembiayaan merupakan salah satu faktor penunjang utama dalam keberlanjutan usaha mikro. Usaha mikro diharapkan mampu mengelola keuangan perusahaan secara profesional untuk kepentingan dan keberlanjutan bisnis mereka. Tujuan studi ini adalah untuk menguji keterampilan literasi keuangan dalam memoderasi pengaruh pembiayaan pada keberlanjutan usaha mikro. Variabel yang diuji adalah pembiayaan, literasi keuangan dan keberlanjutan bisnis. Populasi dalam penelitian ini adalah usaha mikro yang menjalankan kegiatan usahanya di Kabupaten Blora, Jawa Tengah. Jumlah sampel yang digunakan dalam penelitian ini adalah sebanyak 120 usaha mikro, yang ditentukan berdasarkan metode purposive sampling. Alat analisis yang digunakan untuk menguji hipotesis adalah regresi sederhana dan regresi
\end{abstract}


berganda dengan menggunakan SPSS versi 25.0. Hasil penelitian menunjukkan bahwa pembiayaan berpengaruh positif terhadap keberlanjutan usaha mikro dan literasi keuangan memperkuat pengaruh pembiayaan terhadap keberlanjutan usaha mikro. Implikasi penelitian ini adalah pengusaha mikro diharapkan mampu meningkatkan keterampilan literasi keuangan, terutama dalam hal pengelolaan dana karena dana yang diperoleh dari kegiatan pembiayaan rentan terhadap kemungkinan terjadinya penipuan dan kesalahan pengelolaan.

Kata kunci: Pembiayaan, literasi keuangan, keberlanjutan bisnis, usaha mikro

\section{Introduction}

One of the economic sectors that is currently the foundation of Indonesia's economy is micro, small, and medium enterprises (MSMEs). MSMEs have a significant and strategic role in the development and the national economy. In addition to playing a role in economic growth and employment, MSMEs also play a role in distributing development outcomes. MSMEs have also been proven not to be affected by the economic crisis that has occurred in Indonesia (LPPI and Bank Indonesia, 2015). The existence of a populist-based business encourages economic growth through the growth of entrepreneurial spirit (Tagg, 2015). One of the businesses included in MSMEs is micro-enterprises. The existence of micro-enterprises in Indonesia has been regulated in Law Number 20 of 2008, which aims to provide a legal umbrella for microenterprises.

Micro enterprises are productive businesses owned by individuals and/or individual business entities that meet the criteria of micro-enterprises as stipulated in Law Number 20 of 2008. Characteristics of micro-enterprises include a net worth of no more than Rp50,000,000, not including land and buildings. Also, the characteristic of micro-enterprises is to have a maximum annual sale of Rp300,000,000.

The existence of increasingly narrow jobs is a problem of the nation that must be resolved, one of which is by encouraging business among the community, especially among the small and medium-sized communities. Business growth among small and medium-sized communities is expected to be able to open new jobs and new business opportunities. Therefore, the empowerment of MSMEs must be directed. As mandated in Law Number 20 of 2008 concerning MSMEs, the empowerment of MSMEs has the 
aim of realizing economic growth, equity, and increasing people's incomes, job creation, and poverty reduction. The management of UMKM finances must be done professionally by the owner or person who occupies a structural position in charge of financial management. Micro entrepreneurs must have knowledge and skills in the financial field.

The micro-enterprises constraints in Indonesia, according to Bank Indonesia and the Indonesian Banking Development Institute (LPPI) are problems of financing, human resources, law, and accountability, so that the quality of business management needs to be improved. One of the most critical aspects of these constraints is the aspect of financial management. Financial management cannot be separated from the accounting process. Many micro-entrepreneurs have not used accounting in their financial management. Business actors still make complexity as an excuse for not carrying out accounting records properly in their financial management. Micro enterprises people think that the complexity is not comparable to the scale of their business, which is considered relatively small (Puspitaningtyas, 2017). Accounting is a crucial indicator of business performance. Information provided by accounting records is useful as a material consideration for making decisions, to improve the management of the company (Dharma, 2010).

Business actors must have knowledge and skills in the financial field called financial literacy. The definition of literacy, according to the Kamus Besar Bahasa Indonesia (KBBI), is the ability to write, read, and process information, and has knowledge and skills in certain fields or activities. Finance is the science and art of managing money that affects the lives of every person and every organization (Sundjaja et al., 2003). Financial literacy can be interpreted as the knowledge and ability of individuals to manage their money or the organization they manage. If business management is carried out by someone who has good financial literacy, the company will be more assured of its sustainability and future.

One of the company's financial management is management related to corporate financing. According to the Indonesian Banking Development Institute (LPPI), financing is one of the main problems of micro-enterprises in Indonesia. Corporate 
financing is an activity to obtain additional funds from the owner's capital deposits and long-term loans from financial institutions (Boscosianu, 2015). Small companies have the most significant constraints on the limited access to funds in the capital and debt markets (Auken and Neely, 1996). Micro entrepreneurs are expected to be able to take the best policies in terms of corporate financing. Financing policy is a policy related to finding the right type of loan and the best composition between capital and debt to finance business operations (Damodaran, 2014). Following this understanding, it can be explained that financing is related to activities in order to seek additional funds from the capital or debt deposits to support business operations.

Capital is the difference between total assets and total liabilities. In an entity, equity is the owner's interest (Kieso et al., 2019). Capital can be used to carry out daily operational activities and for long-term investments in the form of equipment purchases and business diversification. Good capital management is expected to increase business productivity.

Financing in micro enterprises is also related to the decision to choose the right loan for business operations. The government is trying to encourage the increase of MSMEs by facilitating MSMEs in obtaining loans. Bank Indonesia provides support for financing facilities through banking, namely through people's business credit (KUR). KUR is channeled by state-owned banks, regional banks, and private banks to MSMEs with lower interest rates compared to other loans. According to the Coordinating Ministry for Economic Affairs, the distribution of KUR to MSMEs from January 2018 to June 2018 was Rp64.63 trillion or 55.2\% of the target of Rp117.08 trillion. Bank Indonesia also issued BI Regulation No. 17/12/PBI/2015, which requires commercial banks to have a minimum MSME loan ratio of $20 \%$. The Bank Indonesia Regulation is intended to encourage commercial banks to provide convenience to micro-businesses in financing their businesses. The $20 \%$ minimum lending to MSME players is expected to provide loans from banks capable of encouraging the productivity of micro-enterprises in Indonesia.

One of the micro-business risks is the uncertainty of the sustainability of its business (LPPI and Bank Indonesia, 2015). The uncertainty of micro-businesses is 
caused by the still weak ability of micro-entrepreneurs in managing company finances (Tagg, 2015). Financial management is closely related to the financial literacy capabilities of micro-entrepreneurs. The adequate financial literacy capacity of microentrepreneurs will increase the sustainability of micro-enterprises (Aribawa, 2016). Business sustainability can be seen from the company's success in innovating, managing employees and customers, and regulating returns on initial capital. This shows that companies have an orientation to develop and have opportunities for continuous innovation (Hudson et al., 2001).

Micro enterprise's business risks occur because financial management is still simple, and financial controls are weak, so it is prone to fraud (Tagg, 2015). This shows that business actors' financial literacy skills are needed to manage, control, and supervise the company's finances. Financial literacy is also used to manage funds that have been obtained from corporate financing activities so that management does not occur in error or fraud. Also, adequate financial literacy capability enables microentrepreneurs to gain access to external financing (Beck, 2007). Therefore, financial literacy skills are needed in financing activities and management of funds that have been obtained from financing activities. Good fund management can reduce the level of business risk and maintain business sustainability (Zarcadoolas, 2016).

\section{Theoretical Framework and Hypothesis Development}

\subsection{Financial Literacy}

Literacy refers to a person's ability to read and write (Zarcadoolas et al., 2006). Financial literacy is defined as measuring a person's ability to understand and use financial information. Financial literacy is a part of human ability used in financial management activities to achieve financial prosperity (Huston, 2010).

Financial literacy consists of two dimensions, namely the dimensions of knowledge and dimensions of use. The dimension of knowledge includes one's knowledge and understanding of financial information. Financial knowledge has a narrower meaning than financial literacy (Huston, 2010). While the dimensions of use include the application of financial literacy knowledge to make financial decisions, both dimensions 
in financial literacy are inseparable entities. Based on PISA 2012: Financial Literacy Assessment Framework, it was formulated that financial literacy is a fundamental factor in economic growth and financial stability. According to The Educational Testing Services (ETS), financial literacy capabilities can be measured by understanding financial processes, understanding financial documents, quantitative financial capabilities, and the ability to manage finances.

\subsection{Financing}

Financing is an activity related to finding the right type of financing and the best composition between capital and debt to finance business operations (Damodaran, 2014). Financing a company is related to efforts to obtain financing sources. Micro enterprises financing sources can be obtained from capital and loan deposits. The most common and primary source of micro-enterprises financing is personal money and personal loans from banks because this source has easy access (Auken and Neely, 1996). Financing derived from personal money is referred to as its own capital. Own capital in micro-enterprises is the most simple and traditional financing source because its participation is relatively simple and easy (Boscosianu, 2015). Own capital can come from owner savings, family loans, and funds originating from joint ventures of relatives or family (Auken and Neely, 1996).

Financing originating from its own capital is often unable to meet the operational needs of micro-businesses, so alternative financing sources are needed to meet the operational needs of micro-businesses (Tagg, 2015). Alternative financing can come from loans to financial institutions. Financing originating from loans is now widespread among micro-businesses because of easy terms and procedures (Boscosianu, 2015).

Funds obtained from loans and own capital are used as sources of micro-business financing. According to the Indonesian Banking Development Institute (LPPI), the availability and size of capital are considered to be factors that determine business development for micro-entrepreneurs. The ease of obtaining capital through loans will affect the level of performance of micro-businesses. Capital loans have a significant effect on the level of MSME income (Nisak, 2013). The higher the loan amount, the higher the level of business income (Anggraini \& Nasution, 2013). 


\subsection{Business Sustainability}

The company's ability to provide value-added goods or services both in quality and quantity compared to competitors is one of the determining factors to win the business competition. This is difficult for micro-businesses because of the lack of business management capabilities and limitations in the availability of capital. However, microenterprises tend to have resilience (stable performance) to changes in the business and economic climate (Wu, 2009). This is because micro-businesses are not too dependent on foreign capital.

Business sustainability can be seen from the company's success in conducting business innovation, managing employees and customers, and regulating returns on initial capital. The success of the company in managing the business well shows that the company has an orientation to develop and see opportunities to increase innovation on an ongoing basis (Hudson et al., 2001). In a previous study conducted by Dahmen and Rodríguez (2014), it was found that there was a significant positive relationship between financial literacy and business performance. This relationship occurs in companies with good financial literacy. Companies with sound financial literacy will be able to identify and respond to changes in the business, economic and financial climate so that the decisions taken will create innovative and directed solutions for improving business performance and sustainability.

\subsection{Hypothesis Development}

\subsubsection{Business Financing and Sustainability}

Financing is used to obtain additional funds to carry out daily operational activities. Additional funds can be obtained from long-term loans and owner deposits. Funds that have been obtained need to be managed effectively and efficiently. Fund management must make a positive contribution to the company's performance. In a previous study conducted by Maryama (2015) about the effect of capital structure on company performance, it was found that there was no effect of capital structure on the profitability achieved by the company. This happens because the debt policy undertaken by the company is not fully used for investment or business development. 
In a study conducted by Fachruddin (2011) about the effect of capital structure, firm size, and agency cost on company performance, it was found that the capital structure had a positive effect on company performance. This is due to the use of good debt that will provide good returns on company profitability and company performance. The ease of access in obtaining funds from other parties in the form of loans is expected to be able to improve the quality and quantity of products produced by micro-businesses. Therefore, in this study, the following hypothesis is proposed:

H1. Financing has a positive effect on the sustainability of micro-enterprises.

\subsubsection{Financing, Financial Literacy, and Business Sustainability}

Adequate financial literacy skills of business people can support decision making appropriately for the company. Research on the effect of financial literacy on the performance and sustainability of MSMEs in Central Java conducted by Aribawa (2016) shows that financial literacy has a positive effect on company performance and the sustainability of MSMEs. Financial literacy is able to encourage performance improvement through the quality of decision making that is more precise and fast.

Tambunan (2009) states that MSMEs in Indonesia faces many obstacles, especially in terms of finance and business management problems. The limitations of financial access from external parties are caused by the inability of micro-businesses to provide information on the details of financing and reporting that are in accordance with the standards demanded by external parties (Beck, 2007). Limitations in business management make it difficult for investors and creditors to assess the performance and prospects of micro-businesses in the future, so investors and creditors prefer to invest in companies that are larger than micro-businesses.

Micro enterprises management is more effective and efficient if microentrepreneurs have good financial literacy skills so that the performance and sustainability of micro-businesses can be guaranteed. Therefore, in this study, the following hypothesis is proposed:

H2. Financial literacy strengthens the effect offinancing on the sustainability of microenterprises. 


\subsubsection{Research Model}

This research model is shown in the following figure:

Figure 1

Research Model

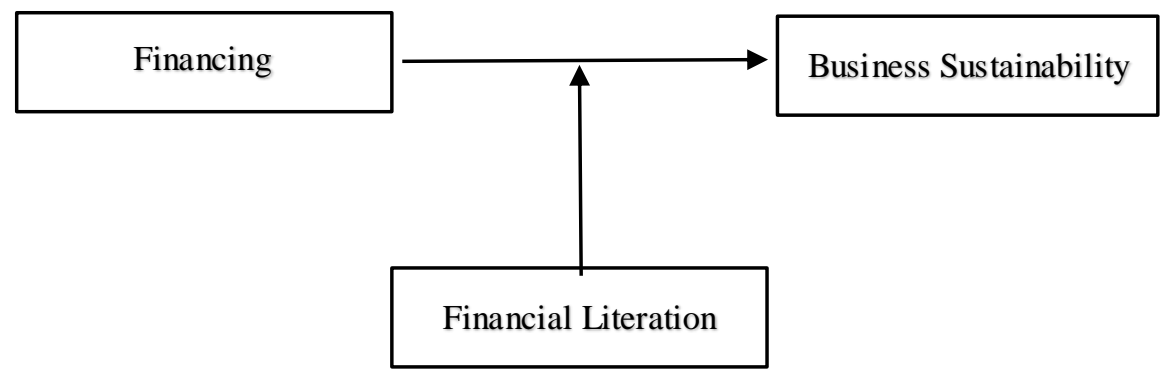

\section{Research Methodology}

\subsection{Research Population and Samples}

The population of this study is micro-businesses in Blora Regency. The selection of samples in this study was conducted using a purposive sampling method with the criteria of micro-businesses as follows:

1. Having a Trading Business License (SIUP) or Small and Medium Business License (IUKM), as well as other business legality documents.

2. Having a permanent business domicile.

3. It has been established for more than one year.

\subsection{Method of Collecting Data}

The type of data in this study is primary data, namely, data obtained directly from data sources. The data in this study were obtained by giving questionnaires to microentrepreneurs. The questionnaire is a method of data collection conducted by giving a set of questions or written statements to respondents to answer (Sugiyono, 2016). Data collection in the form of questionnaires was conducted by giving questionnaires directly to the respondents, and filling out the questionnaire was supervised directly (face to face) by the researcher. This is intended to create comfortable conditions for the respondents so that the questionnaire can run smoothly, and the data obtained is more 
objective. The form of data in this study is in the form of a questionnaire that has been filled in completely by the respondents.

\subsection{Analysis Techniques}

This study uses three data analyzes, namely descriptive analysis, classic assumption test (normality test, multicollinearity test, and heteroscedasticity test), and hypothesis analysis (multiple linear regression analysis and R Square analysis). Testing is done using SPSS version 25 software.

\section{Results and Discussion}

\subsection{Research Object}

The results of descriptive statistical tests of micro-enterprises types can be seen in the following table:

Table 1

Results of Descriptive Statistics of Business Types

\begin{tabular}{|l|l|r|r|r|}
\hline \multicolumn{2}{|c|}{ Type of Business } & Frequency & Percent & Cumulative Percent \\
\hline Valid & Proprietorship & 84 & 70,00 & 70,00 \\
\cline { 2 - 5 } & Partnership & 36 & 30,00 & 100,00 \\
\cline { 2 - 5 } & Total & 120 & 100,0 & \\
\hline
\end{tabular}

Source: Data processed

Table 1 shows that the majority of business types of respondents are proprietorship businesses, namely as many as 84 respondents or $70 \%$ of the total respondents. This is because the majority of businesses owned are hereditary businesses or businesses that are still in the pilot stage. The type of business whose ownership status is a partnership is 36 businesses or $30 \%$ of the total type of business of the respondent.

Descriptive statistical results in the field of micro-enterprises can be seen in the following table: 
Table 2

Results of Descriptive Statistics in Business Fields

\begin{tabular}{|l|l|r|r|r|}
\hline \multicolumn{2}{|c|}{ Business Fields } & Frequency & \multicolumn{1}{c|}{ Percent } & Cumulative Percent \\
\hline Valid & Trading & 36 & 30,00 & 30,0 \\
\cline { 2 - 5 } & Convection & 14 & 11,67 & 41,67 \\
\cline { 2 - 5 } & Craft & 10 & 8,33 & 50,00 \\
\cline { 2 - 5 } & Culinary & 26 & 21,67 & 71,67 \\
\cline { 2 - 5 } & Furniture & 16 & 13,3 & 85,00 \\
\cline { 2 - 5 } & Others & 18 & 15,0 & 100,0 \\
\cline { 2 - 5 } & Total & 120 & 100,0 & \\
\hline
\end{tabular}

Source: Data processed

Table 2 shows the variation in the respondent's business area. Respondents who have businesses in the trade sector, such as clothing, basic necessities, and home products, are as many as 36 people or $30 \%$ of the total respondents. Respondents who have businesses in the field of convection, such as making clothes and pants, curtains are as many as 14 people or equal to $11.67 \%$ of the total respondents. Respondents who have businesses in the field of handicrafts, for example, carvings, ornaments, and house ornaments, are ten respondents or $8.33 \%$ of the total respondents. Respondents who have businesses in the culinary field are 26 people or $21.67 \%$ of the total respondents. Respondents who have businesses in the field of furniture, for example, making tables and chairs, doors, windows, cabinets, beds are as many as 16 respondents or $13.33 \%$ of the total respondents. The remaining 18 respondents or $15 \%$ own businesses in other fields outside the options provided in the questionnaire.

Table 3 shows that the number of micro-businesses with a business duration of 13 years is 28 companies or $23.34 \%$ of the total companies. The number of microenterprises with a business life of 4-6 years is as many as 31 companies or $25.83 \%$ of the total companies. The number of micro-enterprises with a business age of 7-9 years is 31 companies or $25.83 \%$ of the total companies. The number of micro-enterprises that are over nine years old is 30 companies or $25 \%$ of the total companies. 
Descriptive statistical results of business age can be seen in the following table:

Table 3

Business Age Descriptive Test Results

\begin{tabular}{|l|r|r|r|}
\hline \multicolumn{1}{|c|}{ Duration of Business } & Frequency & Percent & Cumulative Percent \\
\hline $1-3$ years & 28 & 23,34 & 23,34 \\
4 - 6 years & 31 & 25,83 & 49,17 \\
\cline { 2 - 4 } $\begin{array}{l}\text { - 9 years } \\
\text { Above 9 years }\end{array}$ & 31 & 25,83 & 75,00 \\
\cline { 2 - 4 } Total & 30 & 25,00 & 100,00 \\
\cline { 2 - 4 } & 120 & 100,0 & \\
\hline
\end{tabular}

Source: Data processed

\subsection{Classical Assumption Test Results}

The normality test is used to find out the data used in the study with normal distribution or not. From the normality test using the Kolmogorov Smirnov test, which is calculated using the SPSS version 25 program, the Asymp value is obtained. Sig of 0.157 . Thus, it can be concluded that the distribution of data from the three research variables is normally distributed because the significance is more than 0.05 .

From the results of the multicollinearity test, the tolerance value is 0.971 , and the VIF value obtained is 1.030. Multicollinearity test results are said to have no multicollinearity relationship because tolerance values are more than 0.1 , and VIF is less than 10.0.

From the heteroscedasticity test results obtained the significance value of the financing variable of 0.114 and the significance value of the financial literacy variable of 0.092 . The results of the heteroscedasticity test showed that there were no symptoms of heteroscedasticity because the significance value was more than 0.05 .

\subsection{Hypothesis Testing}

\subsubsection{Test Individual Parameters ( $t$ value test)}

The results of testing individual parameters are shown in the table 4. 
Table 4

Individual Parameter Test Results

\begin{tabular}{|c|c|c|c|c|c|c|}
\hline \multirow{2}{*}{\multicolumn{2}{|c|}{ Model }} & \multicolumn{2}{|c|}{$\begin{array}{c}\text { Unstandardized } \\
\text { Coefficients }\end{array}$} & \multirow{2}{*}{$\begin{array}{c}\begin{array}{l}\text { Standardized } \\
\text { Coefficients }\end{array} \\
\text { Beta }\end{array}$} & \multirow[t]{2}{*}{$\mathrm{t}$} & \multirow[t]{2}{*}{ Sig. } \\
\hline & & B & Std. Error & & & \\
\hline \multirow{4}{*}{1} & (Constant) & 6.128 & 1.353 & & 4.531 & .000 \\
\hline & Financing & .152 & .059 & .236 & 2.564 & .012 \\
\hline & Financial Literacy & .122 & .054 & .247 & 2.278 & .025 \\
\hline & Moderation & .004 & .002 & .276 & 2.189 & .031 \\
\hline
\end{tabular}

Table 4 shows the results of $t$ count the financing variable positive value of 2.564 and a significance value of $0.012<0.05$. Therefore, it can be concluded that the financing variable has a positive effect on the sustainability of micro-enterprises, so H1 is supported.

Moderation has a positive t count value of 2.189 and a significance value of 0.031 $<0.05$. Therefore, it can be concluded that financial literacy moderates the effect of financing on the sustainability of micro-enterprises. The results of t-test results have not shown that financial literacy strengthens or weakens the effect of financing on business sustainability, so it is necessary to test the coefficient of determination to determine the type and magnitude of its effect.

\subsection{Determination Coefficient Test (R Square)}

In this study, the coefficient of determination was tested twice, the coefficient of determination from financing regression to the sustainability of micro-enterprises before being moderated by financial literacy and the coefficient of determination from the financing regression results for the sustainability of micro-businesses after being moderated by financial literacy variables.

The results of testing the coefficient of determination are shown in the table 5 
Table 5

Determination Coefficient Test Results

\begin{tabular}{|l|r|r|}
\hline \multicolumn{1}{|c|}{ Explanation } & R Square & \multicolumn{1}{|c|}{ Percentage } \\
\hline Before being moderated by financial literacy & 0,181 & $18,1 \%$ \\
After being moderated by financial literacy & 0,377 & $37,7 \%$ \\
Enhancement & 0,196 & $19,6 \%$ \\
\hline
\end{tabular}

Source: Data processed

Table 5 shows the results that the $\mathrm{R}$ square value is 0.181 . This means that $18.1 \%$ of micro-enterprises' sustainability is influenced by financing variables. In contrast, the remaining $81.9 \%$ is influenced by other variables outside the model, such as business premises, human resources, and equipment.

The value of $\mathrm{R}$ square after being moderated is 0.377 . This means that financing variables, financial literacy influence business sustainability variables, and moderation variables are $37.7 \%$, while variables outside of research influence the remaining $62.3 \%$. The value of $\mathrm{R}$ square after being moderated by financial literacy increased by $19.6 \%$ from the previous one of $18.1 \%$ to $37.7 \%$. This shows that financial literacy strengthens the effect of financing on the sustainability of micro-enterprises, so $\mathrm{H} 2$ is supported.

\subsection{Discussion}

The results of this study indicate that financing has a positive effect on the sustainability of micro-enterprises. Large amounts of financing can improve business sustainability. The ease of obtaining credit is expected to be able to meet business needs in fulfilling capital. The funds that have been obtained are expected to be able to be used to support the company's operational activities, such as increasing production capacity through purchasing new equipment and increasing the amount of raw materials. The use of funds for the benefit of the company can guarantee the sustainability of microenterprises.

The results of the study show that financial literacy is able to strengthen the effect of financing on business sustainability. The financial literacy capabilities of microentrepreneurs make financial management better and more planned. Micro 
entrepreneurs who have financial literacy will manage the company's finances effectively and efficiently so that the use of funds will be prioritized to the interests of the company. The use of funds that prioritize business will improve company performance so that business sustainability can be guaranteed.

\section{Conclusion, Limitations, Suggestion, and Implication}

\subsection{Conclusion}

Based on the research that has been done, some conclusions can be taken as follows: Financing has a positive effect on the sustainability of micro-enterprises. This means that the more open access to business financing from various parties and the more amount of additional funds obtained, the more sustainable business sustainability. Further, financial literacy strengthens the effect of financing on the sustainability of micro-enterprises. This is indicated by the higher level of financial literacy of microentrepreneurs, the management of funds obtained from financing activities will be oriented to the interests of the company.

\subsection{Limitations and Suggestions}

Many micro-entrepreneurs who became respondents did not understand the meaning of the study, so many respondents were hesitant and afraid to fill out the questionnaire. This is because research is rarely done with the object of research by micro-entrepreneurs in Blora Regency. The process of data collection in this study takes a long time because the researcher must explain the purpose and objectives of the study thoroughly and clearly so that the respondents do not feel hesitant, disturbed and offended during the process of collecting data.

Future studies are expected to be able to use more effective ways and approaches to respondents during the data collection process. This needs to be done to convince respondents to be willing to provide objective answers. The key is that respondents feel unhappy and hesitant in giving answers is to create a conducive atmosphere at the time of conducting research. The more often respondents are invited to interact, the atmosphere will be more conducive than just watching the respondents when filling out the questionnaire without any interaction. 


\subsection{Research Implications}

Micro entrepreneurs are expected to improve financial literacy skills, especially in terms of managing funds. This is because the funds that have been obtained from financing activities are prone to fraud and errors in management, so professional manage ment needs to be done so that their use is on target. In addition to the misuse of capital management, the incorporation of corporate finance with personal finance is a problem that often occurs in micro-enterprises. Most of the money derived from operating profits are used for personal gain so that micro-entrepreneurs run business activities with makeshift funds. As a result, the business cannot develop significantly.

The government is expected to be able to make policies, among others, in the form of socialization and training in terms of improving financial literacy skills widely to micro-entrepreneurs. Socialization and training can also be in the form of the introduction of information technology, such as the introduction of online transaction systems and the introduction of marketing systems through e-commerce and social media. Increasingly sophisticated technological advancements require businesses to be able to utilize and expand their business network so that they can continue to run and develop better in the future.

\section{Reference}

Anggraini, D \& Nasution, S, H. (2013). Peranan Kredit Usaha Rakyat (KUR) Bagi Pengembangan UMKM di Kota Medan (Studi Kkasus Bank BRI). Jurnal Ekonomi dan Keuangan Universitas Sumatra Utara, 1(3), 105-116.

Aribawa, D. (2016). Pengaruh Literasi Keuangan Terhadap Kinerja dan Keberlangsungan UMKM di Jawa Tengah. Jurnal Siasat Bisnis, 20(1), 1-13.

Auken, Howard E, Van, and Neely, Lynn. (1996). Evidence of Bootstrap Financing Among Small Start-Up Firms. Journal of Entrepreneurial and Small Business Finance, 5(3), 235-249.

Beck, T. H. L. (2007). Financing Constraints of SMEs in Developing Countries: Evidence, Determinants, and Solutions. In Financing Innovation-Oriented Businesses to Promote Entrepreneurship. Unknown Publisher. 
Boscosianu, Mircea. (2015). Innovative Instruments for SME Financing in Romania-A New Proposal with Interesting Implications on Markets and Institutions. Procedia Economics and Finance, 32(1), 240-255.

Damodaran, Aswath. (2014). Applied Corporate Finance. 4th Edition. New York: Wiley.

Dahmen, Pearl \& Rodríguez, E. (2014). Financial Literacy and the Success of Small Businesses: An Observation from A Small Business Development Center. Numeracy, 7(1), 3-16.

Dharma, T. Ediraras. (2010), Akuntansi dan Kinerja UKM. Jurnal Ekonomi Bisnis Universitas Gunadarma. 15(2), 152-158.

Fachruddin, K A. (2011). Analisis Pengaruh Struktur Modal, Ukuran Perusahaan, dan Agency Cost Terhadap Kinerja Perusahaan. Jurnal Akuntansi dan Keuangan Universitas Petra, 13(1). 37-46.

Hudson, M., A. Smart \& M. Bourne. (2001). Theory and practice in SME's performance measurement systems. International Journal of Operations \& Production Management, 21(8), 1096-1115.

Huston, S, J. (2010). Measuring Financial Literacy. The Journal of Consumer Affairs, 44(2), 296-316.

Kieso, Donald E., Jerry J. Weygandt \& Terry D. Warfield. (2019). Intermediate Accounting. Twelfth Edition. New York: Wiley.

LPPI \& Bank Indonesia. (2015). Profil Bisnis Usaha Mikro, Kecil dan Menengah. Jakarta: LPPI.

Maryama, F, D. (2015). Pengaruh Struktur Modal Terhadap Kinerja Perusahaan. Electronic Thesis \& Desertation. Universitas Gadjah Mada.

Nisak, Khoirun. (2013). Pengaruh Pinjaman Modal Terhadap Pendapatan Usaha Mikro, Kecil dan Menengah di Kota Mojokerto. Jurnal Pendidikan Ekonomi (JUPE), 1(3), 1-12.

OECD \& INFE. (2012). PISA 2012: Literacy Assessment Framework, Report Paper.

Peraturan BI Nomor 17/12/PBI/2015 tentang Perubahan Atas Peraturan Bank Indonesia Nomor 14/22/PBI/2012 tentang Pemberian Kredit atau Pembiayaan oleh Bank Umum dan Bantuan Teknis Dalam Rangka Pengembangan Usaha Mikro, Kecil, dan Menengah).

Puspitaningtyas, Zahra. (2017). Pembudayaan pengelolaan keuangan berbasis akuntansi bagi pelaku usaha kecil dan menengah. Jurnal Akuntansi Universitas Jember, 21(3), 361372.

Sugiyono. (2016). Metode Penelitian Kuantitatif, Kualitatif dan $R \& D$. Bandung: Alfabeta.

Sundjaja, Ridwan S. \& Inge, B. (2003). Managemen Keuangan Konsep dan Penerapannya. Jakarta: Literata Lintas Media. 
The Indonesian Journal of Accounting Research - Sept, Vol. 22, No.2, 2019

Tagg, Stephen. (2015). The Happy Story of Small Business Financing. Journal of Banking \& Finance, 31(9), 2648-2672.

Tambunan, Tulus, T, H. (2009), SME's in Asian Developing Countries. 1st Edition. London: Palgrave Macmillan.

Undang-Undang Republik Indonesia Nomor 20 Tahun 2008 Tentang Usaha Mikro, Kecil dan Menengah.

Wu, Dongling. (2009). Measuring Performance in Small and Medium Enterprises in the Information \& Communication Technology Industries. RMIT University Thesis.

Zarcadoolas, C, Andrew, P \& Greer, D. (2006). Advancing Health Literacy: A Framework for Understanding and Action. San Francisco: Jossey-Bass. 